\title{
Kemampuan Mengajar Pengajar BIPA (Bahasa Indonesia bagi Penutur Asing) dalam Pelatihan Tingkat Dasar se-Kota Bengkulu melalui Model Induktif Partisipatif
}

\author{
Arono \\ (corresponding author) \\ Universitas Bengkulu, Indonesia \\ Email: arono@unib.ac.id \\ Wisma Yunita \\ Universitas Bengkulu, Indonesia \\ Email: wismayunita@unib.ac.id \\ Ildi Kurniawan \\ Universitas Bengkulu, Indonesia \\ Email: ildikurniawan@unib.ac.id
}

\begin{abstract}
APA Citation: Arono, A., Yunita, W., \& Kurniawan, I. (2021). Kemampuan mengajar pengajar BIPA (bahasa Indonesia bagi penutur asing) dalam pelatihan tingkat dasar se-Kota Bengkulu melalui model induktif partisipatif. Silampari Bisa: Jurnal Penelitian Pendidikan Bahasa Indonesia, Daerah, dan Asing, 4(1), 107-121. https://doi.org/10.31540/silamparibisa.v4i1.1248
\end{abstract}

\begin{abstract}
Abstrak
Setiap guru yang terlatih dalam mengajar dipengaruhi oleh pengalaman dan intensitas berlatih dalam mengajar. Namun, dalam kenyataannya masih terdapat guru yang kadangkala sudah lama megajar, tetapi masih kurang terlatih dalam melakukan praktik mengajar yang profesional apalagi dalam mengajar BIPA. Penelitian ini bertujuan mendeskripsikan kemampuan mengajar pengajar BIPA tingkat dasar dengan model induktif partisipatif. Metode penelitian ini menggunakan metode deskriptif kualitatif. Teknik pengumpulan, yaitu observasi, tes, angket, wawancara, dan praktik mengajar. Teknik analisis datanya, yaitu rekapitulasi, tabulasi, analisisvdan deskripsi, dan pencatatan atau transkripsi. Uji keabsahan datanya dengan triangulasi. Adapun hasil dari penelitian ini, yaitu penguasaan pemahaman materi BIPA oleh peserta pelatihan sebelum pelatihan (rata-rata 65.12) dan sesudah pelatihan (85.68) mengalami peningkatan sebesar $21 \%$. Aspek yang menjadi indikator penguasaan peserta dalam penguasaan materi BIPA, yaitu metodologi, bahan ajar, media, RPP, dan evaluasi. Kemampuan mengajar peserta dalam mengajar BIPA tingkat dasar sudah baik (4.09). Namun, ada beberapa aspek yang perlu dicermati dalam kemampuan mengajar BIPA walaupun sudah baik, seperti aspek proses penilaian (3.91) dan refleksi dan rangkuman (3.79). Keberhasilan itu dilakukan dengan model pelatihan induktif partisipatif dengan mengikuti enam tahap, yaitu pembinaan keakraban, identifikasi, perumusan tujuan dan diskusi kelompok, penyusunan program, proses pelatihan, dan penilaian proses pelatihan. Model induktif partispiatif yang diterapkan akan menghasilkan kemampuan mengajar yang lebih baik bila disajikan secara sistematis maupun bertahap atau disesuaikan dengan materi pelatihan.
\end{abstract}

Kata kunci: kemampuan mengajar, pengajar BIPA, pelatihan, model induktif partisipatif 
Arono, Wisma Yunita, Ildi Kurniawan

Kemampuan Mengajar Pengajar BIPA (Bahasa Indonesia bagi Penutur Asing) dalam Pelatihan Tingkat Dasar se-Kota Bengkulu melalui Model Induktif Partisipatif

\title{
Teaching Ability of BIPA Teachers (Indonesian Language for Foreign Speakers) in Basic Training in Bengkulu City through the Participatory Inducive Model
}

\begin{abstract}
Every teacher who is trained in teaching is influenced by the experience and intensity of practicing in teaching. However, in reality there are still teachers who sometimes have been teaching for a long time, but are still poorly trained in carrying out professional teaching practices, especially in teaching BIPA. This study aims to describe the teaching ability of BIPA teachers at the basic level with a participatory inductive model. This research method uses a qualitative descriptive method. Descriptively describes the mastery and teaching abilities of BIPA teachers at the basic level, while qualitatively it describes the processes and activities of the trainees through a participatory inductive model. The results of this study, namely the mastery of understanding BIPA material by training participants before training (average 65.12) and after training (85.68) increased by $21 \%$. Aspects that become indicators of participants' mastery in mastering BIPA material, namely methodology, teaching materials, media, lesson plans, and evaluation. The teaching ability of participants in teaching BIPA at the basic level is good (4.09). However, there are several aspects that need to be observed in the ability to teach BIPA even though it is good, such as aspects of the assessment process (3.91) and reflection and summary (3.79). This success was carried out with a participatory inductive training model by following six stages, namely fostering intimacy, identification, formulation of goals and group discussions, program preparation, training process, and assessment of the training process. The participatory inductive model that is applied will produce better teaching skills if it is presented systematically or gradually or adapted to the training material.
\end{abstract}

Keywords: teaching skills, BIPA teachers, training, participatory inductive models

\section{A. Pendahuluan}

Minat belajar bahasa Indonesia oleh pemelajar internasional saat ini meningkat. Hal tersebut dilihat dari banyaknya penyelenggara BIPA di dunia, yaitu ada 355 penyelenggara dari 41 negara dengan total pemelajar 72.746 untuk belajar bahasa Indonesia (Badan Bahasa, 2021). Kondisi pandemi saat ini tidak mengalami pengurangan pemelajar untuk belajar bahasa Indonesia bahkan pemelajar lebih antusias dengan adanya sistem belajar jarak jauh atau daring. Selain upaya menginternasionalkan bahasa Indonesia, pemelajar juga mempunyai tujuan tersendiri hal itu dengan tingginya minat belajar pemelajar asing dalam hal ekonomi, dunia kerja, politik, pendidikan, dan wisatawan. Berbagai program dilakukan untuk melatih dan menyiapkan pengajar BIPA agar handal dan berpengalaman dalam mengajar BIPA, baik di luar negeri maupun dalam negeri. Hal itu dengan dibuktikannya adanya pelatihan pengajar BIPA pada setiap jenjang, dari tingkat dasar sampai tingkat lanjut.

Di Provinsi Bengkulu lebih kurang 73 pengajar BIPA yang aktif sebagai pegiat BIPA, sedangkan sebagai pengajar $7.5 \%$ atau sekitar 10 orang baru bisa dikatakan sebagai pengajar. Dikatakan sebagai pengajar BIPA jika sudah memiliki pengalaman mengajar BIPA minimal 300 jam (AD-ART APPBIPA, 2016). Dengan diadakannya pelatihan model ini pengajar BIPA Provinsi Bengkulu berjumlah 123 orang pegiat/pengajar dari berbagi profesi, seperti dosen, guru, mahasiswa, pengelola kursus, dan kantor bahasa yang ada di Provinsi Bengkulu. Banyaknya peminat pegiat dan pengajar BIPA di Bengkulu sangat memungkinkan potensi untuk mengajar BIPA, baik secara daring maupun tatap muka. Secara tatap muka maupun daring bisa 
Arono, Wisma Yunita, Ildi Kurniawan

Kemampuan Mengajar Pengajar BIPA (Bahasa Indonesia bagi Penutur Asing) dalam Pelatihan Tingkat Dasar se-Kota Bengkulu melalui Model Induktif Partisipatif

dilakukan dengan mengikuti kegiatan seleksi pengajar BIPA ke luar negeri melalui Kemendikbud dan Aminef, Fulbright, atau bisa juga secara volunteer/relawan mengajar di kampus pada saat mahasiswa asing melakukan student excange atau mengajar mahasiswa asing yang berkunjung ke Bengkulu ataupun melalui daring pemelajar yang minat belajar BIPA. Selain itu, penelitian dalam bentuk pelatihan ini dilakuan untuk menyiapkan pengajar-pengajar BIPA yang handal terutama di perguruan tinggi. Beberapa perguruan tinggi negeri dan swasta sudah memiliki program BIPA atau mata kuliah BIPA. Dengan penelitian model pelatihan ini juga dapat menambah keterampilan sebagai seorang pengajar BIPA yang bisa memberikan pengalaman nyata kepada mahasiswanya dalam perkuliahan.

Penelitian pelatihan tentang BIPA saat ini masih sangat terbatas sehingga disentesiskan dari pelatihan pengajaran bahasa yang relevan. Beberapa penelitian yang berhubungan dengan model pelatihan dapat dilihat BP-PLSP REG III (2004) menunjukkan bahwa model pelatihan pamong pelajar mampu meningkatkan kemampuan menulis karya ilmiah kepada peserta pelatihannya. Somarya (2009) dalam penelitiannya dapat meningkatkan mutu pembelajaran, menulis analitik, dan bekal bagi persyaratan kenaikan pangkat serta pengajuan sertifikasi guru. Begitu juga dengan Ismiati dkk. (2010) bahwa semua peserta mengikuti kegiatan dengan motivasi tinggi dan sungguh-sungguh. Hal yang tidak kalah pentingnya dalam pelatihan ini adanya kegiatan peer teaching atau dalam bentuk micro teaching. Cahyati (2014) mengemukakan bahwa nilai kematangan guru dipengaruhi oleh micro teaching dan PPL sebesar $28,5 \%(0,285)$, sedangkan $71,5 \%$ dipengaruhi oleh variabel lain. Arono (2018) mengemukakan bawa aspek melakukan variasi dan pengelolaan kelas masih kurang maksimal yang dilakukan mahasiswa dalam menerapkan pembelajaran micro teaching. Hal tersebut terlihat pada pola interaksi, pengalihan penggunaan sensorik, mengembangkan kemampuan berpikir, saling membantu, dan meningkatkan pemahaman siswa masih kurang terlihat. Oleh karena itu, diperlukan model pembelajaran, refleksi, dan pembinaan atau pelatihan micro teaching yang lebih efektif lagi. Hal ini diperkuat oleh Arono dan Arsyad (2020) dengan model induktif partisipatif dapat memberikan peningkatan kemampuan menulis karya ilmiah bagi peserta pelatihan, namun masih kurang terlihat mengkaji bagaimana pengembangan model pelatihan tersebut dalam pelaksanaannya sampai pada evaluasinya.

Pengajaran BIPA pada umumnya hampir sama dengan pengajaran pada umumnya. Hal yang membedakan dari pengajaran umumnya, yaitu tingkatan materinya dan pemelajaranya. Kedua hal itulah yang membedakan secara prinsip dengan pembelajaran pada umumnya. Kalau teori pembelajaran pada umumnya, pembelajaarn BIPA hampir sama, seperti metode pembelajaran, penguasaan kemampuan mengajar, media, evaluasi, format RPP-nya, maupun perangkat pengajaran lainnya. Menurut Musfah (2011) kompetensi guru dapat diperoleh melalui pendidikan, pelatihan, dan belajar mandiri dengan memanfaatkan sumber belajar. Untuk menciptakan peserta didik yang berkualitas, guru harus menguasai empat kompetensi (Undang-Undang Nomor 14 Tahun 2005 tentang Guru dan Dosen), yakni pedagogik, profesional, sosial, dan kepribadian.

Kompetensi guru di Indonesia telah dikembangkan oleh Proyek Pembinaan Pendidikan Guru (P3G) (Sagala. 2011), yaitu menguasai bahan, mengelola program belajar-mengajar, mengelola kelas, menggunakan media belajar, menguasai landasan pendidikan, mengelola interaksi belajar-mengajar, menilai prestasi belajar, 
mengenal fungsi bimbingan, menyelenggarakan administrasi sekolah, dan menafsirkan hasil pengajaran. Hal ini diperkuat oleh Joni (1997) yang mengasumsikan ada tujuh yang mendasari perangkat kompetensi guru, yaitu hakikat manusia, masyarakat, pendidikan, subjek didik, guru, belajar mengajar, dan kelembagaan. Berdasarkan hal tersebut di atas, penulis menyimpulkan bahwa kompetensi guru dalam mengajar mencakup prapembelajaran, membuka pelajaran kegiatan inti pembelajaran (penguasan materi pelajaran, pendekatan/strategi pembelajaran, pemanfaatan media pembelajaran, pembelajaran yang memicu dan memelihara keterlibatan siswa, penilaian proses dan hasil belajar, dan penggunaan bahasa), serta menutup (refleksi dan rangkuman pembelajaran). Indikator pembelajaran inilah yang menjadi acuan instrumen penulis dalam melakukan praktik pembelajaran BIPA.

Kemampuan mengajar guru selain faktor pengalaman dan pendidikan juga seringnya melakukan intensitas pembelajaran atau praktik mengajar yang penulis sebut dengan model induktif partisipatif. Murdick dan Ross (dalam Amirin, 2001:70) mendefinisikan istilah model merupakan abstraksi realitas bagian-bagian tertentu. Model itu merupakan penggambaran sistem yang nyata atau direncanakan. Hal ini dikuatkan oleh Notoatmodjo (1998:25) bahwa model sebagai suatu bentuk proses pendidikan untuk meningkatkan kemampuan atau ketrampilan khusus seseorang atau kelompok. Sebagai suatu pelatihan model ini merupakan konsep program yang bertujuan meningkatkan pengetahuan dan keterampilan seseorang agar mampu berkembang (Kamil, 2003). Berdasarkan penjelasan tersebut, model pelatihan merupakan gambaran secara utuh dan menyeluruh proses pendidikan untuk meningkatkan keterampilan dimulai dari tahap perencanaan, tahap pelaksanaan, dan tahap evaluasi.

Model induktif menekankan pada usaha yang dilakukan dari pihak yang terdekat, langsung, dan bagian-bagian ke arah pihak yang luas, dan menyeluruh (Kamil, 2003). Oleh karena itu, melalui pendekatan ini diusahakan secara langsung pada kemampuan yang telah dimiliki setiap sasaran didik (pelatihan), kemudian membandingkannya dengan kemampuan yang diharapkan atau harus dimiliki sesuai dengan tuntutan yang datang kepada dirinya. Model ini digunakan untuk mengidentifikasi jenis kebutuhan belajar yang bersifat kebutuhan terasa (felt needs) atau kebutuhan belajar dalam pelatihan yang dirasakan langsung oleh peserta pelatihan. Pelaksanaan identifikasinya pun harus dilakukan secara langsung kepada peserta pelatihan itu sendiri. Untuk itu, model pendekatan ini digunakan bagi peserta pelatihan yang sudah ada (hadir menjadi peserta pelatihan). Model pelatihan induktif partisipatif menekankan pada proses pembelajaran, kegiatan belajar dalam pelatihan dibangun atas dasar partisipasi aktif (keikutsertaan) peserta pelatihan dalam semua aspek kegiatan pelatihan, mulai dari kegiatan merencanakan, melaksanakan, sampai pada tahap menilai kegiatan pembelajaran dalam pelatihan. Upaya yang dilakukan pelatih pada prinsipnya lebih ditekankan pada motivasi dan melibatkan kegiatan peserta (Kamil, 2003).

Model ini sangat tepat dalam penerapan pelatihan karena peserta betul-betul dilatih, baik secara mandiri maupun kelompok dalam mengajar BIPA. Tidak hanya itu, peserta diberikan wawasan pengetahun dan keterampilan yang cukup tentang BIPA mulai dari penyeleksian atau rekrutmen, identifikasi kebutuhan, menentukan tujuan, pelatihan, dan evaluasi. Berdasarkan hal tersebut tujuan penelitian ini untuk 
Arono, Wisma Yunita, Ildi Kurniawan

Kemampuan Mengajar Pengajar BIPA (Bahasa Indonesia bagi Penutur Asing) dalam Pelatihan Tingkat Dasar se-Kota Bengkulu melalui Model Induktif Partisipatif

mendeskripsikan kemampuan mengajar pengajar BIPA tingkat dasar dengan model induktif partisipatif. Adapun mafaat dari penelitian ini memberikan pengalaman langsung kepada peserta dalam praktik mengajar BIPA. Selain itu, peserta dapat meningkatkan kemampuan mengajar BIPA sehingga layak dalam mengajar BIPA dalam kondisi yang nyata.

\section{B. Metodologi Penelitian}

Metode dalam penelitian ini menggunakan metode deskriptif kualitatif. Secara deskriptif menggambarkan kemampuan peguasaan dan kemampuan mengajar BIPA oleh peserta pelatihan, sedangkan secara kualitatifnya menggambarkan proses dan aktivitas kegiatan pelatihan dari hari pertama sampai hari ketiga pelatihan. Model pelatihan induktif partisipatif mampu meningkatkan penguasaan pemahaman guru dalam mengajar BIPA dan kemampuan praktik mengajar bagi guru BIPA tingkat dasar. Model pelatihan induktif partisipatif inilah yang dijadikan implementasi dalam bentuk pelatihan karena mampu menggambarkan secara nyata dalam setiap rangkaian aktivitas peserta dan kemampuannya dalam mengajar (Wiratha, 2006 dan Strauss, 2007).

Teknik pengumpulan data dalam penelitian ini menggunakan observasi langsung, tes soal kemampuan penguasaan profesional guru BIPA, angket penilaian kemampuan mengajar peserta, wawancara untuk melihat permasalahan lebih mendalam dari setiap permasalahan peserta dan praktik mengajar. Observasi dilakukan untuk melihat aktivitas praktik mengajar dan penerapan model induktif partisipatif dalam pelaksanaan pelatihan. Tes diberikan untuk mengukur kemampuan pemahaman awal dan akhir peserta terhadap penguasaan materi BIPA. Angket digunakan sebagai penilaian terhadap kemampuan mengajar pengajar BIPA dalam melaksanakan praktik mengajar. Adapun praktik mengajar dilakukan saat peserta melakukan peer teaching dalam menerapkan pembelajaran BIPA di kelas kelompok kecil. Masing-masing kelompok rata-rata 10 orang. Adapun teknik analisis datanya, rekapitulasi dan tabulasi hasil tes dan angket, analisis, dan deskripsi aktivitas dalam pelatihan sesuai dengan permasalahan, dan pencatatan atau transkripsi. Uji kabsahan datanya dilakukan dengan cara triangulasi. Triangulasi ini dilakukan antarinstrukur dalam melihat dan menganalisis penilaian kemampuan mengajar masing-masing peserta, yaitu ada lima instruktur. Begitu juga dengan penerapan model induktif partisipatif, antarinstruktur memberikan masukan dan tanggapan setiap penerapan model yang dikembangan dari setiap tahapannya. Adapun yang menjadi standar keberhasilan dalam pelatihan ini, yaitu penguasaan materi pembelajaran BIPA dan kemampuan mengajar/peer teaching peserta pelatihan. Hal itu dapat dilihat dari tabel di bawah ini.

Tabel 1. Indikator Keberhasilan Pelatihan Pengajar BIPA Tingkat Dasar

\begin{tabular}{cll}
\hline \multicolumn{2}{c}{ Interval } & Kreteria \\
\hline Pemahaman Materi & Peer Teaching & \\
\hline $1-20$ & $1.00-1.80$ & Rendah \\
\hline $21-40$ & $1.81-2.60$ & Kurang \\
\hline $41-60$ & $2.61-3.40$ & Cukup \\
\hline $61-80$ & $3.41-4.20$ & Baik \\
\hline $81-100$ & $4.21-5.00$ & Sangat baik \\
\hline
\end{tabular}

Silampari Bisa: Jurnal Penelitian Pendidikan Bahasa Indonesia, Daerah, dan Asing Vol. 4, No. 1, June 2021 
Arono, Wisma Yunita, Ildi Kurniawan

Kemampuan Mengajar Pengajar BIPA (Bahasa Indonesia bagi Penutur Asing) dalam Pelatihan Tingkat Dasar se-Kota Bengkulu melalui Model Induktif Partisipatif

\section{Hasil Penelitian dan Pembahasan \\ 1. Hasil Penelitian}

Pelatihan model induktif partisipatif dilakukan setelah adanya kesediaan peserta untuk mengikuti pelatihan pengajar BIPA tingkat dasar se-Kota Bengkulu yang terdiri atas, dosen, mahasiswa, dan guru. Adapun ketentuannya adalah dosen bahasa Indonesia atau bahasa Inggris yang belum pernah mengikuti pelatihan pengajar BIPA tingkat dasar sebelumnya, mahasiswa semester enam atau akhir, guru bidang studi bahasa Indonesia atau bahasa Inggris, dan pengajar atau instruktur kursus bahasa Indonesia atau bahasa Inggris. Beragamnya peserta dalam pelatihan ini diharapkan dapat melahirkan pengajar-pengajar BIPA yang handal dan bersinergi dengan pengajar BIPA lainnya dalam rangka membuanakan bahasa Indonesia baik di daerah, regional, nasional, maupun internasional. Penerapan model induktif partisipatif dalam pelatihan ini dilaksanakan selama tiga hari tanggal 15 s.d. 17 Maret 2021 di Aula Hotel Nala Sea Side Jalan Pariwisata No. 13, Tanah Patah, Kecamatan Ratu Agung, Kota Bengkulu 38111. Pelatihan ini dilakasanakan selama tiga hari atau sama dengan 24 jam pertemuan. Kegiatan ini diawali dengan pemberian pemahaman materi berupa kebijakan pengajaran BIPA, seperti program BIPA, kebijakan BIPA, dan Permendikbud BIPA nomor 27 tahun 2017. Namun, sebelum pemberian materi semua peserta dites pemahaman awal tentang pembelajaran BIPA, seperti aspek metodologi, bahan ajar, media, evaluasi, dan RPP sebanyak 25 soal. Hasil penguasaan pemahaman peserta terhadap pembelajaran BIPA dapat dilihat dari tabel berikut.

Tabel 2. Penguasaan Pemahaman Materi BIPA Peserta

\begin{tabular}{lcc}
\hline \multicolumn{1}{c}{ Deskripsi } & $\begin{array}{c}\text { Nilai Sebelum } \\
\text { Penerapan Model }\end{array}$ & $\begin{array}{c}\text { Nilai Sesudah } \\
\text { Penerapan } \\
\text { Model }\end{array}$ \\
\hline Total pemerolehan nilai dari 25 soal & 3256 & 4284 \\
Rata-rata nilai $(n=50)$ & 65.12 & 85.68 \\
Kategori penguasaan pemahaman & Baik & Sangat Baik \\
\hline Kenaikan penguasan pemahaman & \multicolumn{2}{c}{$20.56(21 \%)$} \\
\hline
\end{tabular}

Tabel 2 di atas menunjukkan bahwa penguasaan pemahaman materi BIPA oleh peserta pelatihan sebelum pelatihan (rata-rata 65.12) dan sesudah pelatihan (85.68) mengalami peningkatan sebesar 21\%. Aspek yang menjadi indikator penguasaan peserta dalam penguasaan materin BIPA, yaitu metodologi, media, RPP, dan evaluasi. Dari kelima aspek tersebut peserta mengalami kesulitan pada aspek evaluasi dan metodologi pembelajaran. Namun, setelah dilakukan pelatihan, peserta mampu memahami dan menguasai kelima aspek dengan baik. Hal yang mendasar yang menjadi permasalahan bagi peserta terutama disebabkan karena peserta mayoritas belum pernah mengajar orang asing, jadi metodologi dan evaluasi yang diberikan jauh berbeda jika dibandingkan dalam pembelajaran bahasa Indonesia pada umumnya. Dalam pelatihan peserta mendalami konsep-konsep pembelajaran BIPA serta mempraktikkannya di dalam kelas, seperti dalam bentuk latihan, simulasi, diskusi, dan penugasan. Hal itu banyak dilakukan pada hari pertama dan kedua, 
Arono, Wisma Yunita, Ildi Kurniawan

Kemampuan Mengajar Pengajar BIPA (Bahasa Indonesia bagi Penutur Asing) dalam Pelatihan Tingkat Dasar se-Kota Bengkulu melalui Model Induktif Partisipatif

sedangkan hari ketiganya peserta berlatih mengajar BIPA dalam bentuk micro teaching.

Hari ketiga ini peserta selama enam jam melakukan praktik mengajar. Masingmasing peserta mendapatkan kesempatan mengajar rata-rata 20 menit. Setiap kelompok terdiri atas 10 peserta dengan satu orang instruktur yang diberi nama kelompok berdasarkan nama negara, yaitu Australia, Hawaii, USA, dan UK. Berdasarkan nama negara tersebut diharapkan peserta dapat menyesuaikan dengan karakter pemelajarnya dan peserta berperan seperti pemelajar di negara mana peserta belajar. Hal itu secara tidak langsung peserta dan calon tenaga pengajar juga belajar budaya negaranya. Adapun hasil kemampuan mengajar pengajar BIPA tingkat dasar seperti terlihat dari tabel berikut ini.

Tabel 3. Penguasaan Kemampuan Mengajar BIPA

\begin{tabular}{clcc}
\cline { 1 - 3 } No. & \multicolumn{1}{c}{ Aspek yang Diamati } & Skor Rata-rata & Ketegori \\
\cline { 1 - 3 } I & Prapembelajaran & 4.08 & Baik \\
\hline II & Membuka Pelajaran & 4.28 & Sangat Baik \\
\hline III & Kegiatan Inti Pembelajaran & & \\
1 & Penguasan Materi Pelajaran & 4.23 & Sangat Baik \\
2 & Pedekatan/Strategi Pebelajaran & 4.01 & Baik \\
3 & Pemanfaatan Media Pembelajaran & 4.18 & Baik \\
4 & Pembelajaran yang memicu dan & 4.14 & Baik \\
& memelihara keterlibatan siswa & & \\
5 & Penilaian proses dan hasil belajar & 3.91 & Baik \\
6 & Penggunaan bahasa & 4.19 & Baik \\
\hline IV & Penutup & \multirow{2}{*}{3.79} & Baik \\
1 & Refleksi dan rangkuman & & \\
& pembelajaran & 4.09 & Baik \\
\hline & Rata-rata & &
\end{tabular}

Berdasarkan tabel 3 di atas menunjukkan bahwa kemampuan mengajar peserta dalam mengajar BIPA tingkat dasar sudah baik (4.09). Itu artinya secara umum peserta sudah siap dan pantas menjadi pengajar BIPA. Dari tabel tersebut ada beberapa aspek yang perlu dicermati dalam kemampuan mengajar BIPA walaupun sudah baik, seperti aspek proses penilaian (3.91) dan refleksi dan rangkuman (3.79). Hal itu disebabkan pengajar lebih banyak mengajar dengan metode ceramah dan kurang mampu mengatur atau merencanakan waktu mengajar dengan baik sehingga pada bagian akhir pembelajaran tidak maksimal bisa diterapkan dengan baik.

Beberapa catatan dari instruktur pada kegiatan praktik peer teching ini di antaranya, secara keseluruhan peserta pelatihan sudah baik dalam mengajar, tetapi masih dalam konteks pemelajaranya orang Indonesia masih belum mengarah atau memahami konteks pemelajar asing, peserta lebih banyak menggunakan metode ceramah sehingga sedikit peserta menggunakan media pembelajaran berbasis teknologi apalagi dengan adanya pandemi menuntut peserta melakukan pembelajaran daring. Kemudian, peserta masih kurang maksimal dalam menata waktu penyajian saat mengajar, serta peserta kurang maksimal menyiapkan perangkat pembelajaran dengan baik, seperti RPP dan media pembelajarannya.

Adapun model pelatihan induktif partisipatif yang dilakukan dalam pelatihan pengajar BIPA tingkat dasar telah dilakukan dengan memperhatikan beberapa tahapan: 
Arono, Wisma Yunita, Ildi Kurniawan

Kemampuan Mengajar Pengajar BIPA (Bahasa Indonesia bagi Penutur Asing) dalam Pelatihan Tingkat Dasar se-Kota Bengkulu melalui Model Induktif Partisipatif

\section{a. Teknik dalam Tahap Pembinaan Keakraban}

Tahap ini digunakan untuk mencairkan suasana agar lebih akrab. Hal itu dapat dilakukan dengan memperkenalkan diri, menyapa peserta secara perorangan atau kelompok, memperkenalkan materi dengan berbagai metode, dan menggali informasi pengalaman peserta dalam pengajaran BIPA, seperti bertanya dengan peserta terhadap topik yang akan dibahas dan menggunakan metode bercerita pengalaman yang akrab dari intruktur dan peserta. Selain itu, pelatih juga memberikan informasi berbagai pengalaman-pengalaman unik yang dialami saat instruktur melakukan kegiatan mengajar BIPA di luar negeri. Selain itu, pelatih memberikan catatan-catan budaya yang perlu menjadi perhatian sebagai calon pengajar BIPA agar bisa menguasai kelas dengan baik. Hal lain yang dilakukan pelatih, pelatih memperlihatkan tayangan-tayangan yang dapat mengggali potensi pemahaman peserta terhadap pengajaran BIPA, seperti simbol-sombol budaya negara dan pemelajarnya.

b. Teknik yang Dipergunakan pada Tahap Identifikasi

Tahap ini bisa dilihat dari latar belakang peserta, seperti pesertanya ada dari mahasiswa, guru, instruktur, dan dosen. Berdasarkan hal tersebut dalam kegiatan diskusi atau pembagian kelompok bisa disebar peserta agar setiap kelompok terdapat latar belakang peserta yang bervariasi. Hal itu dilakukan agar bisa memberikan pembelajaran sebaya atau tukar informasi dalam menggali potensi di setiap peserta, seperti dosen tentu pengalaman dan wawasannya jauh lebih baik dibandungkan mahasiswa sehingga peserta yang lain dapat belajar dari peserta yang lainnya. Hal itu dilakukan juga pada saat peer teaching, peserta yang lain tampil yang dianggap bagus dan berpengalaman bisa menjadi role model atau contoh perbaikan pada penampilan peserta berikutnya, demikian seterusnya atau sebaliknya. Beberapa peserta juga sudah melakukan pembelajaran dengan orang asing yang bisa dibagikan pengalaman kepada peserta lainnya atau telah melakukan kegiatan pelatihan sejenis. Selain itu juga, dalam hal merancang perangkat pembelajaran, media, metode, penilaian, dan RPP, peserta lain akan terbantu dalam penyelesaiannya.

c. Teknik dalam Tahap Perumusan Tujuan dan Diskusi Kelompok

Tahap ini dilakukan sejak disusunnya materi pelatihan selama tiga hari, yaitu hari pertama bertujuan untuk melatih pemahaman peserta terhadap kebijakan dan perkembangan dalam kurikulum BIPA, hari kedua bertujuan memberikan pemahaman peserta pada berbagai aspek pembelajaran serta mampu menyiapkannya, seperti media, metode, bahan ajar, evaluasi, dan RPP-nya. Hari ketiga peserta berlatih melakukan praktik mengajar sehingga peserta terampil mengajar BIPA yang profesional. Mulai hari kedua peserta sudah merumuskan topik apa yang akan dilakukan dalam praktik mengajar dalam bentuk menyusun RPP-nya dengan segala perangkat pembelajaran lainnya. Hari kedua ini juga peserta sudah melakukan diskusi kelompok dan mengerjakan tugas secara mandiri dalam menyiapkan perangkat pembelajaran BIPA.

\section{d. Teknik pada Tahap Penyusunan Program}

Setelah peserta memahami materi ke-BIPA-an pada hari pertama, peserta memahami materi sekaligus merancang program kegiatan pembelajaran pada hari ke dua agar pada hari ketiganya, peserta tinggal melakukan praktik mengajar saja atau peer teaching. Dalam menyusun program pembelajaran BIPA, peserta menentukan sendiri level apa dan materi apa yang akan diajarkan sesuai dengan penguasaan dan ketersediaan bahan yang akan diajarkan oleh setiap peserta. Namun, dalam 
Arono, Wisma Yunita, Ildi Kurniawan

Kemampuan Mengajar Pengajar BIPA (Bahasa Indonesia bagi Penutur Asing) dalam Pelatihan Tingkat Dasar se-Kota Bengkulu melalui Model Induktif Partisipatif

pelaksanaannya sebagian besar peserta kurang merencanakan program dengan baik sehingga pada saat pengajaran atau praktik mengajar kurang ada persiapan mengajar, seperti media pembelajaran dan alat penilaian dalam pembelajaran masih sangat terbatas. Dalam pelaksanaan peer teaching ini peserta diberi kesempatan untuk mengajar minimal 20 sampai dengan 25 menit setiap orang dan peserta dikomentari atau diberi masukan sambil memberikan penilaian setiap akhir pembelajaran oleh instruktur.

e. Teknik yang Dipergunakan dalam Proses Pelatihan: Penyajian Materi atau

Ceramah, Diskusi Kelompok, Penugasan Individu, dan Peer Teaching

Tahapan ini merupakan teknik secara keseluruhan dalam kegiatan pelatihan. Teknik dalam pelatihan sudah tergambar dalam setiap susunan acara pelatihan dari hari pertama sampai hari ketiga, yaitu hari pertama teknik ceramah, diskusi, dan tanya jawab karena lebih banyak membahas materi. Hari kedua lebih pada teknik ceramah, dikusi, tanya jawab, dan penugasan, sedangkan hari ketiga teknik penyajian pelatihan menggunakan praktik bermain peran sebagai pengajar dan sebagai pemelajar dalam bentuk kelompok. Teknik pelatihan di hari ketiga ini lebih kompleks dengan berbagai metode dan strategi yang digunakan oleh pengajar dalam praktik mengajarnya. Praktik ini dibagi dalam lima kelompok dengan berbagai karakter pemelajar berdasarkan asal negaranya. Berbagai teknik pelatihan digunakan ini agar peserta pelatihan mampu memahami dan berlatih sebagai pengajar BIPA yang profesional.

f. Teknik yang Dapat Dipergunakan dalam Penilaian Proses Pelatihan, Hasil dan

Pengaruh Kegiatan: Respons Terinci, dan Pengajuan Pendapat Tertulis

Tahapan ini merupakan indikator keberhasilan dalam pelatihan yang dilakukan sehingga tahap ini tidak hanya dilakukan di akhir, tetapi di awal pelatihan sudah dilakukan penilaian agar dapat dilihat perkembangan dan kemajuan penguasaan kemampuan pengajar BIPA tingkat dasar pada akhir pelatihan. Di awal pelatihan lebih menggali penguasaan pemahaman awal peserta terhadap materi pembelajaran BIPA, yaitu media, metode, bahan ajar, evaluasi, dan perangkat pembelajaran BIPA/RPP begitu juga di akhir kegiatan diukur kemampuan peserta sehingga terdapat peningkatan penguasaannya $21 \%$ dalam kegiatan pelatihan ini. Selain itu, penilaian yang tidak kalah pentingnya mengukur kemampuan pengajar BIPA dalam praktik pembelajaran BIPA pada setiap peserta. Setiap peserta melakukan praktik mengajar akan diberikan penilaian dan refleksi oleh instruktur dan peserta pelatihan di dalam kelompoknya agar penguasaan peserta dalam mengajar BIPA menjadi lebih baik lagi. Penilaian selain secara tertulis, juga pelatihan ini dilakukan penilaian melalui respons dari peserta kegiatan dengan melakukan wawancara dari beberapa peserta terhadap pelatihan yang telah dilakukan, misalnya dengan mengapresiasi peserta yang melakukan praktik mengajarnya lebih baik/terbaik daripada peserta lainnya. Apresiasi yang diberikan, yaitu adanya uang pembinaan dari peserta yang terbaik tiga besar dan sepuluh besar dengan bingkisan berupa buku bacaan ilmiah pengajaran BIPA.

\section{Pembahasan}

Kemampuan mengajar pengajar BIPA tingkat dasar dengan model induktif partisipatif ini menjadi baik (4.09) dengan perincian dua aspek sangat baik dan delapan aspek lainnya baik. Penguasaan peserta dalam mengajar BIPA jika dilihat dari sudut pandang pemelajar masih tergolong homogen. Artinya dalam realitanya pemelajar BIPA mayoritas heterogen, baik dari segi usia, pendidikan, maupun pekerjaan. Hal yang membedakan antarpemelajar dilihat dari segi usia sehingga 
Arono, Wisma Yunita, Ildi Kurniawan

Kemampuan Mengajar Pengajar BIPA (Bahasa Indonesia bagi Penutur Asing) dalam Pelatihan Tingkat Dasar se-Kota Bengkulu melalui Model Induktif Partisipatif

dalam penerapan pembelajaran perlakukan pengajarnya akan berbeda kecuali jika pengajar BIPA mengajar di sekolah atau perguruan tinggi/pendidikan formal. Hal ini disampaikan oleh Hertiki (2017) bahwa pemelajar BIPA di Polandia memiliki latar belakang pendidikan dan tujuan yang berbeda dalam mengikuti kelas BIPA. Pengajaran BIPA yang dilaksanakan di Indonesia sangat jauh berbeda dengan kelas BIPA yang ada di Polandia. Hal itu kesannya kurang terlatih yang dimiliki oleh pengajar BIPA saat ini sehingga perlu diadakannya berbagai metodologi pelatihan dengan berbagai tingkatan dan berkelanjutan (Nugraheni, 2015). Variasi dengan berbagai konteks pemelajar menjadikan pengajar akan lebih profesional dalam mengajar BIPA ke depannya. Hal berbeda ketika peserta pelatihan yang sudah memiliki pengalaman dalam perkuliahan BIPA di kampusnya, peserta demikian sudah memiliki pengalaman mengajar akan lebih baik begitu juga dengan pengalaman peserta sebagai guru.

Model pelatihan induktif partisipatif yang menekankan pada proses pembelajaran atas dasar partisipasi aktif (keikutsertaan) mulai dari kegiatan merencanakan, melaksanakan, sampai pada tahap menilai kegiatan pembelajaran dalam pelatihan (Kamil, 2003) telah mampu meningkatkan pemahaman, penguasaan, dan keterampilan mengajar pengajar BIPA tingkat dasar hal itu dilihat dari tes awal pemahaman BIPA dan akhirnya (85.68/sangat baik), serta kemampuan mengajar pengajar BIPA pada saat peer teaching-nya (4.09/baik). Metode induktif partisipatif ini telah mampu meningkatkan pemahaman peserta pelatihan dengan baik, seperti beberapa penelitian yang telah dilakukan oleh Setiawan (2017), Surti \& Jailani (2017), Karyati (2018), Yunita dkk. (2019), dan Arono \& Arsyad (2020). Namun, di dalam pelaksanaannya ada beberapa faktor yang sangat memengaruhinya dalam memperkuat penerapan model pelatihannya. Penerapan model induktif partisipatif ini memiliki beberapa faktor pendukung yang perlu dipertahankan dalam penerapannya, diantaranya Kantor Bahasa Provinsi Bengkulu sebagai lembaga pemerintah resmi yang salah satu kegiatannya dalam Program BIPA dengan melaksanakan pelatihan pengajar BIPA hampir setiap setahun sekali sangat peduli dan aktif terhadap perkembangan dan kemajuan BIPA yang ada di Bengkulu pada khususnya. Kepedulian tersebut disambut baik oleh APPBIPA Cabang Bengkulu sebagai organisasi independen terdiri atas pegiat dan pengajar BIPA di Bengkulu bahkan di luar negeri sehingga bisa bekerja sama dan bersinergi dengan Kantor Bahasa Provinsi Bengkulu dalam memajukan BIPA yang ada di Bengkulu.

Hal lainnya yang mendukung dalam penerapan model ini, yaitu kondisi peserta. Peserta sangat menentukan keberhasilan dalam menerapkan suatu model pelatihan terutama dalam hal kualitas (Rustiana, 2010 dan Suci \& Jamil, 2019). APPBIPA Cabang Bengkulu yang anggotanya terdiri atas pegiatan dan pengajar BIPA yang ada di Bengkulu maupun pengalaman mengajarnya sampai ke luar negeri memiliki potensi dalam mengembangkan BIPA dan memajukan BIPA yang ada di Bengkulu. Peserta pelatihan yang beragam memberikan variasi dan pemahaman baru dalam kegiatan pelatihan sehingga bisa saling mengisi dan belajar dalam memajukan pembelajaran yang lebih inovatif, variatif, dan mutakhir dalam pelatihannya. Peserta pelatihan memberikan respons positif terhadap kegiatan ini dengan telah mengikuti pelatihan dari awal hingga akhir pelatihan dan mereka sangat antusias dalam mengikuti rangkaian acara yang diberikan. Semua peserta telah mengikuti rangkaian pelatihan 
Arono, Wisma Yunita, Ildi Kurniawan

Kemampuan Mengajar Pengajar BIPA (Bahasa Indonesia bagi Penutur Asing) dalam Pelatihan Tingkat Dasar se-Kota Bengkulu melalui Model Induktif Partisipatif

melakukan praktik mengajar BIPA sebagai pengalaman yang berharga dalam pondasi mereka mengajar BIPA.

Penerapan model ini juga memberikan apresiasi kepada peserta yang memiliki kemapuan lebih dibandingkan dengan peserta lainnya. Hal itu dilakukan sebagai bentuk motivasi dan penghargaan kepada peserta (Widagdo \& Susilo, 2018). Peserta memiliki kemampuan lebih atau sepuluh besar terbaik dalam praktik menngajar BIPA diberikan penghargaan uang pembinaan dan bingkisan. Semua peserta mendapatkan sertifikat pelatihan dari Kantor Bahasa Bengkulu sebagai bukti dan apresiasi kepada peserta yang telah mengikuti pelatihan dengan baik. Sertifikat tersebut bisa digunakan sebagai salah satu persyaratan mengikuti seleksi mengajar ke luar negeri oleh Kemendikbud atau institusi lain. Tempat pelatihan yang luas dan memadai juga menjadikan peserta sangat nyaman dan aman dalam mengikuti pelatihan, apalagi saat masa pandemi memerlukan ruangan yang lebih luas karena kapasitas pesertanya sudah 50 orang. Selain itu, minat peserta kegiatan ini cukup tinggi, tetapi karena hanya dibatasi 50 orang sehingga pesertanya diseleksi dan dibatasi. Semua peserta yang telah mengikuti pelatihan ini memenuhi persyaratan untuk menjadi anggota di APPBIPA Cabang Bengkulu.

Adapun sebagai faktor penghambat yang perlu diminimalisasi jika menerapkan model induktif partisipatif dalam pelatihan ini dipengaruhi oleh faktor internal dan eksternal (Nurjaman dkk., 2017; Laksana dkk., 2017). Faktor eksternalnya, yaitu (1) Ruang yang cukup luas dalam kegiatan pelatihan, namun saat peserta praktik mengajar atau peer teaching peserta mengalami kendala. Hal itu karena ruangan praktik mengajar untuk settingnya seperti kelas tidak ada mengakibatkan peserta kurang konsentrasi dalam mengajar sehingga berpengaruh juga dengan media mengajar yang kurang tersedia dengan baik. Peserta dalam hal ini harus memaksimalkan menyiapkan media pembelajaran secara mandiri dan kreatif. (2) Praktik dalam menyiapkan perangkat pembelajaran sangat terbatas sehingga banyak peserta yang kurang siap dalam menyiapkan perangkat pembelajaran. Untu itu, peserta dituntut lebih kreatif dan inovatif dalam menyiapkan perangkat pembelajarannya. Peserta tidak hanya mengandalkan materi dari instruktur semata melainkan lebih kreatif dalam mengakses dan menyiapkan materi mengajar yang lebih inovatif.

Adapun faktor internal yang memengaruhi dalam pelatihan ini sehingga perlu diminimalisasi permasalahannya, yaitu (1) Peserta yang latar belakangnya masih mahasiswa atau bahkan belum mengambil mata kuliah micro teaching dan apalagi bukan latar belakangnya pendidikan akan mengalami kesulitan dalam memahami dan praktik mengajar BIPA. Untuk itu, peserta memerlukan ekstra belajar mandiri dalam penguasaan dan berlatih mengajar sevara mandiri. (2) Peluang mengajar BIPA di Bengkulu masih sangat terbatas. Itu artinya pengajar BIPA yang ada di Bengkulu harus aktif dalam mencari peluang mengajar BIPA baik secara tatap muka maupun mengajar online atau jarak jauh kepada orang asing atau bisa juga menjadi tenaga pengajar BIPA relawan kepada orang asing yang berkunjung ke Bengkulu secara personal ataupun kelembagaan. (3) Pelatihan ini dilaksanakan secara tatap muka saat pandemi. Kondisi ini menghambat dan membatasi ruang gerak instruktur dan peserta. Hal itu bisa disiasati dengan pembelajaran atau pelatihan online atau dengan pelatihan blended learning sehingga penguasaan peserta dalam mengajar BIPA lebih kontekstual dan sesuai dengan kebutuhan pemelajar saat pandemi ini. 
Arono, Wisma Yunita, Ildi Kurniawan

Kemampuan Mengajar Pengajar BIPA (Bahasa Indonesia bagi Penutur Asing) dalam Pelatihan Tingkat Dasar se-Kota Bengkulu melalui Model Induktif Partisipatif

Penerapan model pelatihan ini berdampak pada tingginya minat peserta terhadap pembelajaran BIPA, baik di dalam negeri maupun luar negeri. Hal itu mengakibatkan banyaknya pengajar dan kesiapan pengajar BIPA yang ada di Bengkulu untuk mengajar BIPA sehingga semakin kompetetif dan profesional dalam mengajar BIPA (Eliyanto \& Wibowo, 2013; Rahmawati, 2015; Rakib dkk., 2016; Fitria dkk., 2019). Selain itu, profesional mengajar bahasa Indonesia akan semakin baik dan berkualitas serta lebih peduli terhadap pemakaian bahasa Indonesia. Secara keorganisasian menjadikan kekuatan dalam memajukan dan mengembangkan BIPA di Bengkulu dengan bersinerginya kegiatan APPBIPA Cabang Bengkulu terhadap Kantor Bahasa Bengkulu dalam memajukan dan mengembangkan program kegiatan BIPA pada masa yang akan datang. Hal itu akan berdampak pada bertambahnya keanggotaan organisasi APPBIPA Cabang Bengkulu baik sebagai pegiat maupun pengajar BIPA.

Penerapan model pelatihan ini juga akan melahirkan pengajar-pengajar muda yang profesional dan peduli dalam mengajar BIPA di Bengkulu, nasional, bahkan internasional untuk berkompetensi mengikuti seleksi pengajaran BIPA ke luar negeri. Dengan pengalaman yang banyak dan telah mengikuti pelatihan kesiapan pengajar BIPA di Bengkulu menjadikan lebih siap dan tangguh sebagai pengajar BIPA di manapun berada ditempatkan di seluruh negara di luar negeri. Kepedulian itu bisa juga diwujudkan dengan menjadi relawan mengajar BIPA bagai orang asing yang ada di Bengkulu secara personal ataupun secara lembaga. Selain itu, perkembangan BIPA di perguruan tinggi terutama yang ada program BIPA-nya akan semakin meningkat dan berkembang minat mahasiswa dalam pengajaran BIPA sehingga melahirkan pengajar-pengajar BIPA yang tangguh dan profesional dalam membuanakan bahasa Indonesia.

\section{Simpulan}

Model pelatihan induktif partisipatif telah mampu meningkatan kualitas dan kuantitas peserta pelatihan sebagai pengajar BIPA tingkat dasar lebih profesional dilihat berdasarkan penguasaan pemahaman BIPA dan kemampuan mengajar BIPA yang dilakukan oleh semua peserta pelatihan. Keberhasilan itu dilakukan dengan model pelatihan induktif partisipatif dengan mengikuti enam tahap, yaitu pembinaan keakraban, identifikasi, perumusan tujuan dan diskusi kelompok, penyusunan program, proses pelatihan, dan penilaian proses pelatihan. Tahapan ini dilakukan dalam setiap pelatihan, baik secara sistematis maupun bertahap atau disesuaikan dengan materi pelatihan sehingga diperoleh hasil pelatihan yang baik dan akan lebih baik.

Berdasarkan hasil pelaksanaan dan manfaat yang diterima oleh para peserta yang menjadi peserta dalam penerapan model pelatihan ini, model induktif partisipatif ini lebih baik jika kegiatan ini terus dilanjutkan karena akan sangat membantu calon tenaga pengajar BIPA terutama yang masih pemula dalam kesiapan mengajar BIPA baik di Bengkulu/dalam negeri maupun yang akan mengikuti seleksi mengajar BIPA ke luar negeri. Selain itu, bersinerginya APPBIPA Cabang Bengkulu dengan Kantor Bahasa Bengkulu memberikan perkembangan dan kemajuan program BIPA yang ada di Bengkulu khususnya dan di Indonesia pada umumnya. Dengan hal itu akan melahirkan tenaga-tenaga pengajar BIPA yang profeisonal dan tangguh untuk mengajar BIPA di tingkat nasional bahkan internasional. 
Arono, Wisma Yunita, Ildi Kurniawan

Kemampuan Mengajar Pengajar BIPA (Bahasa Indonesia bagi Penutur Asing) dalam Pelatihan Tingkat Dasar se-Kota Bengkulu melalui Model Induktif Partisipatif

\section{Daftar Pustaka}

AD-ART APPBIPA. (2016). "Anggran dasar dan anggaran rumah tangga APPBIPA Indonesia". http://appbipa.or.id/

Amirin, T. M. (2001). Pokok-pokok teori sistem. Jakarta: PT Raja Grafindo Persada.

Arono, A. \& Arysad, S. (2020). Pelatihan penulisan karya tulis ilmiah bagian abstrak dan pendahuluan model induktif partisipatif pada guru SMA/SMK/MA dan dosen bahasa di Lubuk Linggau dalam peningkatan profesionalitas. Dedication: Jurnal Pengabdian Masyarakat, 4(2), 167-184. https://doi.org/10.31537/dedication.v4i2.365

Arono, A. (2018). "Basic teaching skills of language teachers on microteaching lessons". Advances in Social Science, Education and Humanities Research, volume 253. 3rd Asian Education Symposium (AES 2018). Atlantis Press. https://www.atlantis-press.com/proceedings/aes-18/55917329

Badan Bahasa. (2021). "Badan bahasa targetkan 100.000 pemelajar baru BIPA pada tahun 2024". https://bit.ly/34UrMFX

BP-PLSP REG III. (2004). Model pelatihan pamong belajar ahli berbasis kompetensi. Jawa Tengah: Depdiknas.

Cahyati, A. A. (2014). "Pengaruh mata kuliah microteaching dan praktik pengalaman lapangan (PPL) terhadap tingkat kematangan calon guru pada mahasiswa pendidikan ekonomi akuntansi angkatan 2010 Universitas Muhammadiyah Surakarta". Program Studi Pendidikan Akuntansi FKIP Universitas Muhammadiyah Surakarta.

Eliyanto, E., \& Wibowo, U. B. (2013). Pengaruh jenjang pendidikan, pelatihan, dan pengalaman mengajar terhadap profesionalisme guru SMA Muhammadiyah di Kabupaten Kebumen. Jurnal Akuntabilitas Manajemen Pendidikan, 1(1), 34-47. https://doi.org/10.21831/amp.v1i1.2321

Fitria, H., Kristiawan, M., \& Rahmat, N. (2019). Upaya meningkatkan kompetensi guru Melalui pelatihan penelitian tindakan kelas. Abdimas Unwahas, 4(1), 14-25. http://dx.doi.org/10.31942/abd.v4i1.2690

Hertiki. (2017). Pengajaran dan pembelajaran BIPA di Perguruan Tinggi Polandia. Jurnal pendidikan Bahasa dan Sastra Indonesia, 6(2), 1-5. https://doi.org/10.15294/jpbsi.v6i2.20226

Ismaniati, C. (2011). "Pelatihan penulisan karya ilmiah bagi Kepala SMPN di Lingkungan Diknas Pendidikan Dasar se-Kabupaten Bantul". Yogyakarta: UNY. http://eprints.uny.ac.id/id/eprint/1583 
Arono, Wisma Yunita, Ildi Kurniawan

Kemampuan Mengajar Pengajar BIPA (Bahasa Indonesia bagi Penutur Asing) dalam Pelatihan Tingkat Dasar se-Kota Bengkulu melalui Model Induktif Partisipatif

Joni, T. R. (1979). Pengembangan kurikulum IKIP/FIP/FKG, suatu kasus pendidikan guru berdasarkan kompetensi. Jakarta: P3G Depdikbud.

Kamil, M. (2003). Model-Model pelatihan. Bandung: UPI.

Karyati, K. (2018). Meningkatkan pemahaman materi perkembangan peserta didik menggunakan metode partisipatif dengan grup whatsapp di STKIP PGRI Blitar. Seminar Nasional Pendidikan dan Kewarganegaraan IV. (259-265). http://seminar.umpo.ac.id/index.php/SEMNASPPKN/article/view/185/185

Laksana, Y. S., Sholih, S., \& Naim, M. (2017). Pelatihan tata rias pengantin bagi wanita tuna susila dalam meningkatkan kemandirian usaha. Journal of Nonformal Education and Community Empowerment, 1(1), 43-54. https://doi.org/10.15294/pls.v1i1.14794

Musfah, J. (2011). Peningkatan kompetensi guru melalui pelatihan dan sumber belajar teori dan praktik. Jakarta. Kencana Prenada Group.

Notoatmodjo, S. (1998). Pengembangan sumber daya manusia. Bandung: Rineka Cipta.

Nugraheni, A. S. (2015). Pengembangan program profesionalisme dosen pengajar bahasa Indonesia untuk penutur asing (BIPA) di ASEAN. Al- Bidayah, Jurnal Pendidikan Dasar Islam, 7 (1), 89-102. ps://doi.org/10.14421/albidayah.v7i1.157

Nurjaman, F., Sudadio, S., \& Faturohman, N. (2017). Implementasi pelatihan tari daerah dalam melestarikan tarian Banten di Sanggar Raksa Budaya Kota Serang. Journal of Nonformal Education and Community Empowerment, 1(2), 152-160. https://doi.org/10.15294/pls.v1i2.19414

Rahmawati, S. (2015). Pengaruh pelatihan, pengalaman mengajar dan kompensasi terhadap profesionalisme guru di SMK Negeri 3 Palu. Katalogis, 3(12), 67-75. http://jurnal.untad.ac.id/jurnal/index.php/Katalogis/article/view/6482/5169

Rakib, M., Rombe, A., \& Yunus, M. (2016). Pengaruh pelatihan dan pengalaman mengajar terhadap profesionalitas guru (Studi pada guru IPS terpadu yang memiliki latar belakang pendidikan dalam bidang pendidikan ekonomi). Jurnal Ad'ministrare" Jurnal Pemikiran IImiah dan Pendidikan Administrasi Perkantoran", 3(2), 1-148. https://doi.org/10.26858/ja.v3i2.2574

Rustiana, A. (2010). Efektivitas pelatihan bagi peningkatan kinerja karyawan. JDM (Jurnal Dinamika Manajemen), $\quad 1(2), \quad 137-142$. https://journal.unnes.ac.id/nju/index.php/jdm/article/view/2469/2522

Sagala, S. (2011). Kemampuan profesional guru dan tenaga kependidikan. Bandung: Alfabeta.

Silampari Bisa: Jurnal Penelitian Pendidikan Bahasa Indonesia, Daerah, dan Asing Vol. 4, No. 1, June 2021 
Arono, Wisma Yunita, Ildi Kurniawan

Kemampuan Mengajar Pengajar BIPA (Bahasa Indonesia bagi Penutur Asing) dalam Pelatihan Tingkat Dasar se-Kota Bengkulu melalui Model Induktif Partisipatif

Setiawan, W. E. (2017). Model pembelajaran partisipatif dalam meningkatkan kemandirian perempuan sebagai kepala keluarga. Jurnal Pendidikan Non Formal dan Informal, 7(2), 1-15. https://ejournal.upi.edu/index.php/PNFI/article/view/5587/3793

Somarya, D. (2009). "Pelatihan dan pendampingan pembuatan karya tulis ilmiah bagi guru sekolah dasar di Wilayah Priangan Barat". Jakarta: Dikti.

Strauss, A. \& Corbin, Y. (2007). Dasar-dasar penelitian kualitatif. Yogyakarta: Pustaka Pelajar.

Suci, Y. T., \& Jamil, A. S. (2019). Hubungan tingkat kepuasan pelayanan dengan keberhasilan peserta pelatihan teknis bagi penyuluh pertanian. Jurnal Hexagro, 3(2), 47-55. https://doi.org/10.36423/hexagro.v3i2.279

Surti, W., \& Jailani, M. (2017). Upaya meningkatkan hasil belajar IPS dengan menggunakan metode pemberian tugas dan media kartu tebak kata pada peserta didik di SDN 1 Pulau Telo Kuala Kapuas tahun ajaran 2016/2017. Pedagogik: Jurnal Pendidikan, 14-27. https://doi.org/10.33084/pedagogik.v12i2.853

Widagdo, A., \& Susilo, S. (2018). Pelatihan penulisan artikel ilmiah bagi guru-guru SD di Kecamatan Kendal. Abdimas Unwahas, 3(1), 25-29. http://dx.doi.org/10.31942/abd.v3i1.2234

Wirartha, I. M. (2006). Pedoman penulisan usulan penelitian, skripsi dan tesis. Yogyakarta: Andi.

Yunita, W., Hati, G. M., \& Hardiah, M. (2019). Pelatihan penggunaan scaffolding talk dalam pengembangan instruksi pembelajaran bahasa Inggris bagi guru PAUD inti Kota Bengkulu. Dharma Raflesia: Jurnal Ilmiah Pengembangan dan Penerapan IPTEKS, 69-76. https://doi.org/10.33369/dr.v17i2.10091 